\title{
Seasonal Changes in Growth, Nitrogen Nutrition, and Yield of Hydroponic Lettuce
}

\author{
Desire Djidonou ${ }^{1}$ and Daniel I. Leskovar ${ }^{2,3}$ \\ Texas A\&M AgriLife Research and Extension Center, 1619 Garner Field \\ Road, Uvalde, TX 78801
}

Additional index words. Lactuca sativa, nutrient solution concentration, nutrient film technique (NFT), cropping season

\begin{abstract}
The effect of different nitrogen (N) concentrations on growth changes, leaf $\mathrm{N}$ concentration and accumulation patterns, $N$ nutrition index (NNI), fresh weight yield, and $\mathbf{N}$ use efficiency (NUE) was determined for lettuce grown over three consecutive seasons (fall, winter, and spring) in a recirculating hydroponic system, under unheated and naturally lit hoop house in Uvalde, TX. The lettuce cultivars Buttercrunch, Dragoon, and Sparx were grown at six $N$ concentrations, initially $100,150,200,250,300$, and 400 $\mathrm{mg} \cdot \mathrm{L}^{-1}$ using a nutrient film technique (NFT). Leaf number, accumulated dry weight (DW) and N, and leaf area index (LAI) followed a logistic trend over time, characterized by a slow increase during early growth followed by a linear increase to a maximum. By contrast, plant total $N$ concentrations were the highest at early stage and decreased slightly over time. Effect of season and cultivar on these growth traits was more pronounced than that of the $\mathbf{N}$ concentrations. Averaged across cultivar and $\mathbf{N}$ concentrations, DW in spring was $73 \%$ and $34 \%$ greater than that in fall and winter, respectively. At each sampling date, there were linear, quadratic, or cubic effects of $\mathbf{N}$ concentrations on each of these variables. The cultivar Sparx was the most productive, with $63 \%$ and $32 \%$ higher fresh weight yield in fall, $145 \%$ and $114 \%$ in spring, than 'Buttercrunch' and 'Dragoon', respectively. Increasing nutrient solution $N$ concentrations from 100 to $400 \mathrm{mg} \cdot \mathrm{L}^{-1}$ increased the yield from 5.9 to $6.7 \mathrm{~kg} \cdot \mathrm{m}^{-2}$ in fall, 8.1 to 10.7 $\mathrm{kg} \cdot \mathrm{m}^{-2}$ in winter, and 10.3 to $12.6 \mathrm{~kg} \cdot \mathrm{m}^{-2}$ in spring. The NUE was the highest at the lowest $N$ concentration $\left(100 \mathrm{mg} \cdot \mathrm{L}^{-1}\right)$ and decreased with increasing $N$ concentrations. The NNI during mid- to late-growth stages was near or greater than one, even at the lowest $N$. These results demonstrated that $N$ concentrations of $100-150 \mathrm{mg} \cdot \mathrm{L}^{-1}$ maximized the growth and yield of hydroponically grown lettuce.
\end{abstract}

Lettuce (Lactuca sativa L.), a cool-season leafy vegetable is widely grown throughout the world because of its high consumption and economic value. In the United States, types of lettuce predominantly grown include crisphead (iceberg), cos/romaine, loose leaf (leaf), and butterhead (Mikel, 2007). Commercial production of these types of lettuce is predominantly field grown with heavy reliance on chemical inputs, including synthetic fertilizers and other pesticides (Bottoms et al., 2012). Such intensive and monoculture production systems often present great concerns primarily related to nitrate

\footnotetext{
Received for publication 14 Sept. 2018. Accepted for publication 31 Oct. 2018.

This research was funded by a Texas Department of Agriculture Specialty Crop Block Grant (Project No. SCFB-1314-26).

Appreciation is expressed to Manuel Pagan, Michael Tidwell, Andrea Macias, and Kuan Qin for assistance in the experimental setup and data collection and to Carrie Hensarling for carrying out the nutrients chemical analyses of tissue samples.

${ }^{1}$ Research Associate.

${ }^{2}$ Professor and Center Director.

${ }^{3}$ Corresponding author. E-mail: d-leskovar@ tamu.edu.
}

accumulation that can be detrimental to human and environmental health (Barbosa et al., 2015). More sustainable production systems ensure consumer preferences for clean and healthy produce. Hydroponics is a method of crop culture that emerged decades ago to grow fresh market leafy vegetables in a wide range of environments (Resh, 2012). In particular, NFT is one variant of all hydroponic systems, where a recirculating thin film of nutrient solution flows through plastic channels that hold the growing plants and over the developing root mat of the plants (Putra and Yuliando, 2015).

When compared with the conventional, soil-based cropping system, hydroponic system affords a more efficient use of production inputs, especially water and fertilizers, leading to higher yields (Barbosa et al., 2015; Delaide et al., 2016; Resh, 2012; Rouphael et al., 2004). Unlike crop production under field conditions, which could benefit from soil nutrient mineralization and microorganism activity, hydroponically grown plants are exclusively dependent on direct fertilizer supply to meet their nutritional needs. As such, a sound understanding of crop-specific nutrient requirement for optimal growth and yield with the hydroponic production system is therefore warranted. The management of nutrient concentration is vital and remains a key determinant of yield and quality of vegetable crops in soilless production systems (Fallovo et al., 2009; Maboko and Du Plooy, 2017). This is critical and indispensable for a leafy vegetable such as lettuce, which is characterized by a high sensitivity to $\mathrm{N}$ deficiency (Broadley et al., 2000) and a relatively low $\mathrm{N}$ uptake efficiency (NUpE) (Greenwood et al., 1989). Evidences of growth decline as a result of an interruption in external $\mathrm{N}$ supply have been reported (Walker et al., 2001). Because a continuous supply of $\mathrm{N}$ in the nutrient solution is a prerequisite for normal growth, the ensuing critical question is as follows: what is the optimum $\mathrm{N}$ concentration to use in the nutrient solution to ensure maximum growth and yield? The current literature reports a wide range of $\mathrm{N}$ concentration for maximum growth and yield in hydroponic lettuce production systems (Fallovo et al., 2009; Mahlangu et al., 2016; Resh, 2012; Stefanelli et al., 2011). Gent (2014) reported that concentrations of nitrate in standard nutrient solutions for hydroponics range from 100 to $200 \mathrm{mg} \cdot \mathrm{L}^{-1}$.

Variation in these reported $\mathrm{N}$ concentrations are mainly related to cultivar, season, and type of hydroponic system. Fallovo et al. (2009) suggested the use of 37 and 44 mequiv $\cdot \mathrm{L}^{-1}$ nutrient solution (equivalent to 233 and $277 \mathrm{mg} \mathrm{N} / \mathrm{L}$ ) to achieve maximum yields of lettuce grown in a floating raft culture system during the spring and summer seasons, respectively. Seasonal changes in optimum $\mathrm{N}$ rates could be related to differential responses of cultivars to environmental factors, especially temperature and solar radiation. Variation in light and temperature greatly influences the metabolism of leaves and roots, as well as the rate of assimilate transformation and availability of nutrients in the growing substrate (Gent, 2014; Tei et al., 1996). Moreover, growth traits, including relative growth rate (RGR), net assimilation rate (NAR), and leaf area ratio (LAR), are greatly dependent on the efficiency with which intercepted radiation is transformed into DW (Dapoigny et al., 2000).

Nutrient requirement for maximum growth and yield of a specific crop can also be dependent on the genotype. Different cultivars in the same plant species generally have different requirements, especially for $\mathrm{N}$, phosphorus $(\mathrm{P})$, and potassium $(\mathrm{K})$ (Resh, 2012). The requirement for $\mathrm{N}$ often determines the extent of the plant NUE (Ladha et al., 2005), which is also an indicator of $\mathrm{N}$ fertilizer response (Haegele et al., 2013). NUE quantifies the increase in fresh weight yield per unit of applied fertilizer $\mathrm{N}$ and encompasses both uptake efficiency, which is the ability of plant to remove $\mathrm{N}$ from the soil and utilization efficiency which is the ability of plants to convert acquired $\mathrm{N}$ into the shoot production (Benincasa et al., 2011). Several vegetable species, including spinach (Chan-Navarrete et al., 2014; Stagnari et al., 2007), white cabbage (Erley et al., 2010), and 
potatoes (Sharifi et al., 2007), have demonstrated variability in NUE. This cropgenotypic variation in NUE is mainly due to morphological and functional differences among genotypes, which determine the potential for $\mathrm{N}$ uptake and assimilation (Lammerts van Bueren and Struik, 2017). Given the differences in the morphological traits of the types of commercially grown lettuce (Simko et al., 2014), varietal difference in NUE can be expected as well; however, little is known when these types of lettuce are grown in the hydroponic NFT production system.

The present study explores the extent to which changes in $\mathrm{N}$ requirement for enhanced growth traits, fresh weight yield, and NUE of hydroponic lettuce are influenced by the season and cultivar. The objectives of the study were a) to characterize the growth and $\mathrm{N}$ uptake patterns, and $\mathrm{b}$ ) to determine the fresh weight yield and NUE of three commercially grown lettuce cultivars in response to $\mathrm{N}$ concentrations during three consecutive production seasons in an NFT hydroponic system.

\section{Materials and Methods}

Plant source and seedling production. The study was carried out in an unheated hoop house located at the Texas A\&M AgriLife Research and Extension Center in Uvalde, TX (lat. 29 $12^{\prime} 57.6^{\prime \prime} \mathrm{N}$, long. $99^{\circ} 45^{\prime} 21.6^{\prime \prime} \mathrm{W}$ ) during the fall (OctoberDecember) of 2016, winter (JanuaryMarch) and spring (March-May) of 2017. The hoop house was 29.3-m long $\times 9.1-\mathrm{m}$ wide $\times 6.1-\mathrm{m}$ high covered with $6.0-\mathrm{mm}$ clear polyethylene film. During each cropping cycle, seeds of butterhead (cv. Buttercrunch) and romaine (cvs. Dragoon and Sparx; Johnny's Selected Seeds, Waterville, ME) lettuce types were sown into rockwool slabs (Dk-2640; Grodan A/S, Hedehusene, Denmark) in horticulture trays, which were kept moist with tap water until germination. Germinated seeds were subsequently grown in nutrient solution ranging from 50 to 150 $\mathrm{mg} \cdot \mathrm{L}^{-1} \mathrm{~N}$ for $21 \mathrm{~d}$.

Experimental setup and growth conditions. Lettuce seedlings were transplanted onto six NFT bays each consisting of 10 NFT channels supplied with a continuous and recirculating nutrient solution, on 9 Nov. (fall cycle), 3 Feb. (winter cycle), and 13 Apr. (spring cycle). Each hydroponic channel was $3.65 \mathrm{~m}$ in length with plants spacing of $0.2 \mathrm{~m}$ within channel and $0.17 \mathrm{~m}$ between channels resulting in a plant density of 29 plants $/ \mathrm{m}^{2}$. Each NFT bay was connected to an individual tank (300 L) to supply and recollect the nutrient solution. The solution was automatically pumped at a rate of $1.89 \mathrm{~m}^{3} \cdot \mathrm{h}^{-1}$ to the upper end of each channel and recirculated continuously day and night. The nutrient solution bathes the roots as it flows back to the sump by gravity.

During each cropping season, the experimental design was a split plot with $\mathrm{N}$ concentrations as the main plot factor randomly assigned to each of the six NFT bays.
The six different $\mathrm{N}$ concentrations were 100 , $150,200,250,300$, and $400 \mathrm{mg} \cdot \mathrm{L}^{-1}$. The three lettuce cultivars were the subplot factors randomly assigned within each table with three replications of 18 plants each.

The CNS17 Grow Eq. (3-1-2; Botanicare, LLC, Chandler, AZ), containing 3.0\% total $\mathrm{N}$ with $0.14 \%$ ammoniacal $\mathrm{N}$ and $2.86 \%$ nitrate $\mathrm{N}$; was used to prepare the lowest concentration $\left(100 \mathrm{mg} \cdot \mathrm{L}^{-1}\right)$. Higher $\mathrm{N}$ concentrations $\left(150-400 \mathrm{mg} \cdot \mathrm{L}^{-1}\right)$ were prepared with ammonium nitrate (32-0-0) containing half of the $\mathrm{N}$ in the nitrate form and half in the ammonium form. The concentrations of all other nutrients in the starting solution were adjusted as follows in $\mathrm{mg} \cdot \mathrm{L}^{-1}(\mathrm{ppm}): \mathrm{P}-50 ; \mathrm{K}-$ 215; calcium (Ca)-187; magnesium (Mg)-30; sulfur (S)-43.4; iron (Fe)-3.5; manganese (Mn) -0.14 . The electrical conductivity of each of the starting nutrient solutions ranged between 1.37 and $2.57 \mathrm{dS} \cdot \mathrm{m}^{-1}$ with the $\mathrm{pH}$ adjusted to 6.0. Each bay was also equipped with an automated $\mathrm{pH}$ management system (Bluelab PH Controller; Tauranga, New Zealand) that kept the $\mathrm{pH}$ within the range 5.5-6.5 with addition of $25 \%$ sulfuric acid. Nutrient solutions were aerated with an air pump (Active Aqua Model AAPA7.8-L; Sweetwater, Ft. Collins, CO) connected to an air stone/diffuser in each tank. Nutrient solutions were refreshed every seven to $10 \mathrm{~d}$ throughout the growth cycle when the volume is low.

Climatic parameters inside the hoop house, including hourly temperature, photosynthetic active radiation, relative humidity, and dew point were recorded with a mini station WatchDog data logger (Spectrum Technologies, Inc., Aurora, IL).

Changes in growth variables. During each cropping cycle, starting $14 \mathrm{~d}$ after transplanting (DAT), growth measurements were destructively carried out on one to two plants per treatment and replication at a 7-d interval until the final harvest. After cutting plants at the base, total head fresh weight and leaf number per plant were recorded. Total leaf area was taken using a leaf area meter (LI-3100 leaf area meter; LI-COR, Lincoln, NE). Subsequently, samples were dried in a thermo-ventilated oven at $70{ }^{\circ} \mathrm{C}$ until reaching a constant weight $(\approx 3 \mathrm{~d})$ to determine DW per square meter and LAI. RGR was calculated from these DWs as follows (Hunt, 1982):

$$
\mathrm{RGR}=\frac{\ln \left(W_{2}\right)-\ln \left(W_{1}\right)}{t_{2}-t_{1}},
$$

where RGR is measured in $\mathrm{mg} \cdot \mathrm{g}^{-1} \cdot \mathrm{d}^{-1}, W=$ weight, $t=$ time, and index is date of sampling.

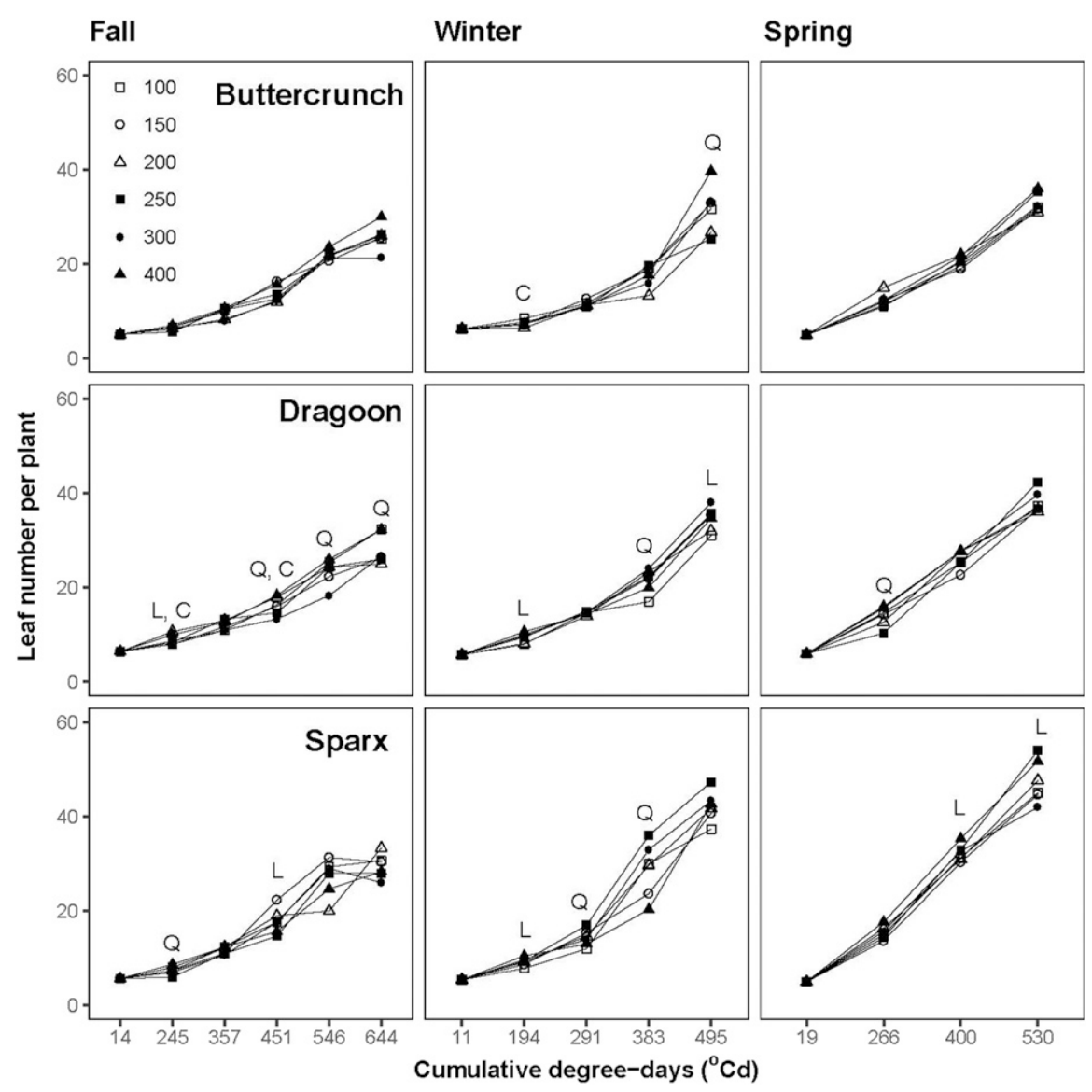

Fig. 1. Leaf number of lettuce cvs. Buttercrunch, Dragoon, and Sparx grown hydroponically at six N concentrations $\left(100,150,200,250,300\right.$, and $\left.400 \mathrm{mg} \cdot \mathrm{L}^{-1}\right)$ as a function of the cumulative degree days during the cropping cycles of fall (October-December), winter (January-March), and spring (AprilMay). Letters represent significant $(P<0.05)$ polynomial contrasts of $\mathrm{N}$ concentrations within each degree day as follows: $\mathrm{L}=$ linear; $\mathrm{Q}=$ quadratic; and $\mathrm{C}=$ Cubic. 
In addition, the growing degree days (GDD) were calculated by subtracting the base temperature from the average daily temperature. Cumulative degree days (CDDs) (thermal time) at each sampling date were then calculated as the sum of daily degree days as follows:

$\mathrm{CDD}_{x}=\sum_{\text {day } 0}^{\text {sampling date } x}\left[\frac{\left(T_{\max }+T_{\min }\right)}{2}-T_{\text {base }}\right]$,

where $T_{\max }$ and $T_{\min }$ represent the maximum and the minimum temperatures recorded on a given day $x$, and $T_{\text {base }}$ is the base temperature. The base temperature of $4{ }^{\circ} \mathrm{C}$ was considered for lettuce (Kristensen et al., 1987). The graphical representations of the relationship between the growth traits and CDD are discussed.

Plant tissue $N$ analysis and calculation of NNI. Dried samples on each sampling date were finely ground using a Foss sample mill (FOSS Cyclotec 1093; Foss North America, Eden Prairie, MN) to pass through a $1-\mathrm{mm}$ screen and were used for quantitative chemical analysis. Total Kjeldahl N (TKN) concentrations in tissues were determined by Kjeldahl method (Easy Chem Plus; Chinchilla Scientific, Oak Brook, IL) with the addition of sulfuric acid for digestion in the presence of Kjeldahl formulated catalyst (Pro-Pac-CT 37; Alfie Packers, Inc., Omaha, $\mathrm{NE})$. Total accumulated $\mathrm{N}\left(\mathrm{Nacc} ; \mathrm{g} \cdot \mathrm{m}^{-2}\right.$ ) was then calculated by multiplying the aboveground DW by the total $\mathrm{N}$ concentration at each sampling date.

Values of NNI during each cropping cycle were also estimated for each sampling date to identify the $\mathrm{N}$ status in the shoot dry matter during the growth cycle. NNI was calculated using the following equation proposed by Lemaire et al. (1989):

$$
\mathrm{NNI}=\frac{\mathrm{N}_{a}}{\mathrm{~N}_{c}},
$$

where $\mathrm{N}_{a}$ represents the measured TKN concentration in the dry tissues and $\mathrm{N}_{c}$ the critical $\mathrm{N}$ concentration calculated based on shoot dry matter using the $\mathrm{N}$ dilution curve given as:

$$
\mathrm{N}_{c}=a \mathrm{DW}^{-b},
$$

where DW is the total shoot DW expressed in $t$. ha $\mathrm{a}^{-1}$ and $a$ and $b$ are species-dependent coefficients. The values of $a$ and $b$ used in this study were 4.56 and 0.357 , respectively as developed for lettuce by Tei et al. (2003). Value of $a$ (4.56) is a coefficient that represents the shoot $\mathrm{N}_{c}$ at $1 t \mathrm{DW} /$ ha; and value of $b(0.357)$ is a coefficient that characterizes the pattern of $\mathrm{N}_{c}$ decrease during growth (Lemaire et al., 2008). As proposed by Justes et al. (1994), the critical $\mathrm{N}$ concentration represents the minimum $\mathrm{N}$ concentration in the aboveground tissues required for maximum growth. Crop $\mathrm{N}$ nutrition status is considered optimum when NNI is 1 , limiting when it is lower than 1, and in excess when it is higher than 1 .
Fresh weight yield, yield components, and NUE indices. During each cropping cycle, fresh weight yield was measured by harvesting five representative heads per replication from the center of each channel when the plants reached marketable size. Harvesting occurred on 22 Dec. 2016 (43 DAT), 10 Mar. 2017 (35 DAT), and 5 May 2017 (27 DAT) for the fall, winter, and spring seasons, respectively. Fresh weight and leaf number of each head were recorded. Fresh weight yield $\left(\mathrm{kg} \cdot \mathrm{m}^{-2}\right)$ was then estimated.

Using data from the final DW and plant $\mathrm{N}$ uptake, NUE [g DW/mg of supplied N $\left(\mathrm{g} \cdot \mathrm{mg}^{-1} \mathrm{~N}\right)$ ] and its components, NUpE [mg of plant $\mathrm{N} / \mathrm{mg}$ of supplied $\mathrm{N}\left(\mathrm{mg} \cdot \mathrm{mg}^{-1}\right)$ ], and $\mathrm{N}$-utilization efficiency (NUtE) [g DW/g of plant $\mathrm{N}\left(\mathrm{g} \cdot \mathrm{g}^{-1} \mathrm{~N}\right)$ ] were also calculated according to definitions reported by Lammerts van Bueren and Struik (2017).

Statistical analysis. Data were analyzed with a PROC GLIMMIX of SAS 9.4 (SAS Institute, 2014). Fresh weight yield, total leaf number, NUE, and its components were analyzed with a model including main effects of season, $\mathrm{N}$ concentration, and cultivar along with the second and third-order interaction terms. Replication within $\mathrm{N}$ concentration and within season $(\operatorname{Rep} \times \mathrm{N} \times$
Season) was considered as a random effect. Orthogonal polynomial contrasts (linear, quadratic, and cubic) were used to compare the type of yield response with the effect of $\mathrm{N}$ concentration in nutrient solution. Multiple means comparisons were also performed using the Tukey's multiple range test $(P<$ 0.05) when a significant Cultivar $\times$ Season interaction was observed on specific response variables. Plots of model residuals were used to check for normal distribution. Regression analyses were also conducted to establish linear relationships between marketable yield and leaf number within each season.

For the growth analysis data, main effects included in the model were season, $\mathrm{N}$ concentration, cultivar, and DAT along with all possible interactions. The growth data were treated as repeated measures and as such an autoregressive covariance structure was used. Polynomial contrasts (linear, quadratic, and cubic) were also used to determine the nature of responses to $\mathrm{N}$ concentrations at each DAT.

\section{Results}

Leaf number development. Regardless of the $\mathrm{N}$ concentration, leaf count of each

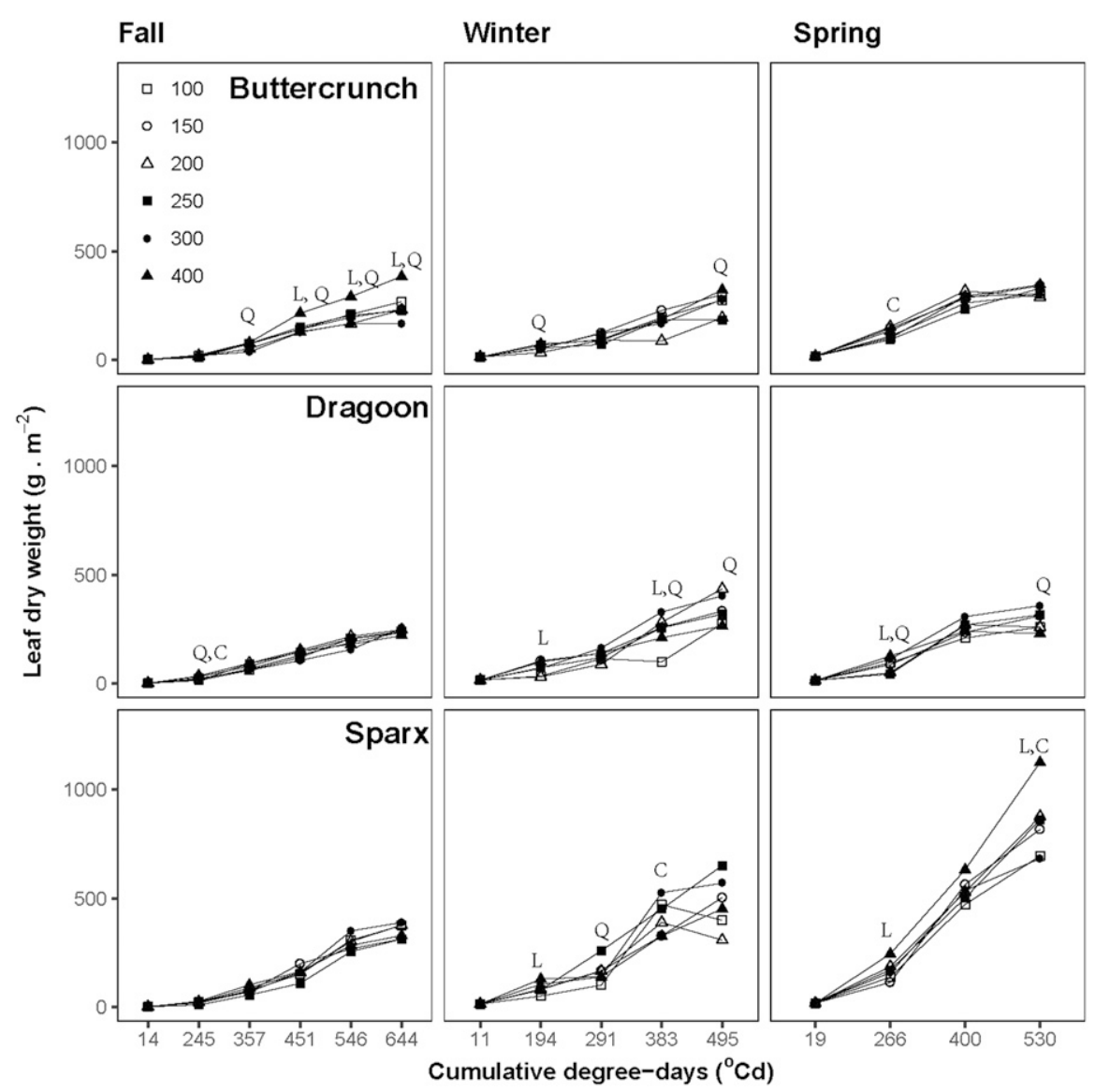

Fig. 2. Total dry weight of lettuce cvs. Buttercrunch, Dragoon, and Sparx grown in nutrient film technique hydroponic culture at six $\mathrm{N}$ concentrations $\left(100,150,200,250,300\right.$, and $\left.400 \mathrm{mg} \cdot \mathrm{L}^{-1}\right)$ as a function of the cumulative degree days during the cropping cycles of fall (October-December), winter (JanuaryMarch), and spring (April-May). Letters represent significant $(P<0.05)$ polynomial contrasts of $\mathrm{N}$ concentrations within each degree day as follows: $\mathrm{L}=$ linear; $\mathrm{Q}=$ quadratic; and $\mathrm{C}=$ cubic. 
cultivar followed a logistic trend with thermal time during each cropping cycle (Fig. 1). A slow rate of leaf appearance during transplant establishment was followed by a rapid rate, leading to a maximum number independent of cultivar. During slow growth in the fall cycle, there were two to four new leaves produced by $14 \mathrm{DAT}$, corresponding to a change of $231{ }^{\circ} \mathrm{C}$ in thermal time, and two to five between 14 and 21 DAT, corresponding to a change of $112{ }^{\circ} \mathrm{Cd}$ in thermal time. By contrast, during rapid growth, leaf development ranged from 7 to 10 new leaves between 28 and $35 \mathrm{DAT}$, for a difference of $95^{\circ} \mathrm{Cd}$ in thermal time. During winter cycle, these changes were three to six new leaves during early growth and 13-14 new leaves during rapid growth between 28 and 35 DAT. Similarly in spring cycle, growth had a slow phase followed with a faster phase. However, in spring, the extent of the slow phase was brief due to warmer temperature. The number of new leaves ranged from 7 to 10 by 14 DAT, corresponding to a difference of $247{ }^{\circ} \mathrm{Cd}$ in thermal time. The number of new leaves ranged from 13 to 17 during rapid growth between the 21 and 28 DAT, for a difference of $130{ }^{\circ} \mathrm{Cd}$. Plants required fewer GDD to develop maximum leaf number in spring than in fall or winter.

During each cropping cycle, $\mathrm{N}$ concentration and cultivar main effects were significant, as were the interactions between $\mathrm{N} \times$ DAT and cultivar $\times$ DAT. Depending on growth cycle and cultivar, leaf number response was linear, quadratic, or cubic with increasing $\mathrm{N}$ concentration. For example, at 14 DAT, a linear response was observed in leaf number of 'Dragoon' during fall and winter cycles, whereas a quadratic response was found in spring. 'Buttercrunch' was less responsive to increasing $\mathrm{N}$ concentration in the nutrient solution than 'Dragoon' and 'Sparx'.

Relative growth rate, $D W$ accumulation and $L A I$. RGR followed a similar pattern over time for all three cultivars. RGR reached maximum values and then decreased with time. RGR was the fastest in spring with a $52 \%$ and $15 \%$ increase at 14 th DAT compared with fall and winter, respectively (data not shown). There was a more rapid DW accumulation in spring, irrespective of the cultivar and $\mathrm{N}$ concentrations (Fig. 2). Regardless of the season, dry matter production was slow during early growth, as seen with the leaf number. Across cultivars and $\mathrm{N}$ concentrations, the percentage of DW at harvest that was accumulated at 14 DAT was just $7 \%, 20 \%$, and $26 \%$ in fall, winter, and spring, respectively. Averaged over all $\mathrm{N}$ concentrations, the maximum increase in DW was reached at $35 \mathrm{DAT}$, corresponding to an accumulated thermal time of $546{ }^{\circ} \mathrm{Cd}$ in fall. In winter, the maximum DW was observed between 21 and 28 DAT, for a differential thermal time of $92{ }^{\circ} \mathrm{Cd}$. The greatest change in DW was reached in spring at an earlier time, between 14 and 21 DAT, which corresponded to an accumulated thermal time of $134{ }^{\circ} \mathrm{Cd}$.
Within each cropping cycle, leaf DW accumulation was affected by both the interaction of $\mathrm{N}$ concentration and DAT $(P<$ $0.0001)$ and by $\mathrm{N}$ concentration $\times$ cultivar $(P$ $<0.0001)$. N concentrations demonstrated a polynomial trend which varied with season and cultivar. In the fall, the DW of 'Buttercrunch' increased quadratically as the $\mathrm{N}$ concentration increased from 100 to 400 $\mathrm{mg} \cdot \mathrm{L}^{-1}$ at 21 DAT $\left(357{ }^{\circ} \mathrm{Cd}\right)$, whereas a cubic trend was observed at 14 DAT $\left(266{ }^{\circ} \mathrm{Cd}\right)$ in spring. 'Dragoon' showed no significant effect on DW measured at harvest in fall, whereas a quadratic response was observed in winter and spring cycles. At final harvest, $\mathrm{N}$ concentrations exhibited linear and quadratic effects on DW of 'Sparx' in spring, whereas there were no effects in fall and winter.

LAI is closely related to accumulated leaf DW and had a gradual increase with thermal time to reach a maximum value that fluctuated depending on the cropping cycle. LAI increased from 0.1 to 0.2 at transplanting, to a maximum ranging from 3.3 to 8.9 at 35 DAT $\left(546{ }^{\circ} \mathrm{Cd}\right)$ in the fall, from 4.6 to 16.4 at 35 DAT $\left(495^{\circ} \mathrm{Cd}\right)$ in the winter, and from 5.7 to 19.6 at 28 DAT $\left(530^{\circ} \mathrm{Cd}\right)$ in the spring (data not shown). The highest LAI for all three cultivars was achieved in spring, with $7 \%$ to
$143 \%$ increase relative to those of fall and winter cropping cycles when averaged over all six $\mathrm{N}$ concentrations.

Nitrogen concentration, accumulation, and NNI. Total Kjeldahl $\mathrm{N}$ concentration showed a slight decrease over time. Plant tissue $\mathrm{N}$ concentrations were the highest in the fall, varying between $2 \%$ and $5 \%$, compared with spring, when values ranged from $1.3 \%$ to $3.1 \%$ of dry matter. By contrast to TKN, total accumulated $\mathrm{N}$ exhibited an increase over time similar to that of the DW accumulation. The accumulated $\mathrm{N}$ was the lowest right after transplant and higher during mid to late growth stages (Fig. 3). Averaged over $\mathrm{N}$ concentrations and cultivars, accumulated $\mathrm{N}$ during early growth at 14 DAT was $9 \%, 20 \%$, and $33 \%$ of total accumulated $\mathrm{N}$ at harvest in fall, winter, and spring, respectively. The proportion of total $\mathrm{N}$ accumulated during rapid growth (28-35 DAT) ranged from $54 \%$ to $88 \%$ of the $\mathrm{N}$ at harvest. Increments in nutrient solution $\mathrm{N}$ resulted in a significant increase in total $\mathrm{N}$ uptake. The response was linear, quadratic, or cubic (Fig. 3). During each season, total $\mathrm{N}$ varied with cultivar. 'Sparx' exhibited a consistently higher $\mathrm{N}$ uptake than that of 'Dragoon' and 'Buttercrunch'. $\mathrm{N}$ uptake in 'Sparx' at harvest in

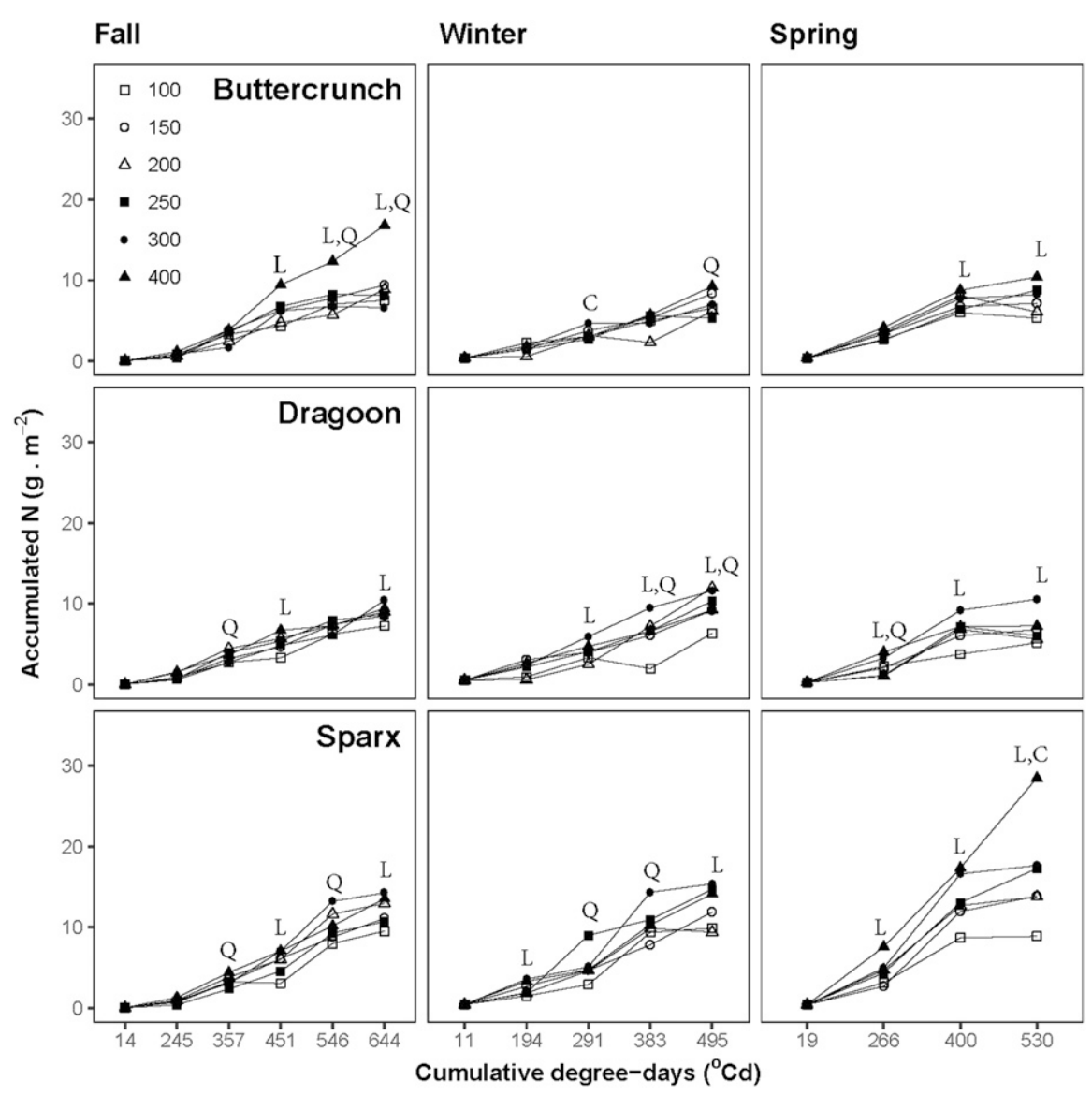

Fig. 3. Total elemental $\mathrm{N}$ of lettuce leaves cvs. Buttercrunch, Dragoon, and Sparx grown in nutrient film technique hydroponic culture at six $\mathrm{N}$ concentrations $\left(100,150,200,250,300\right.$, and $\left.400 \mathrm{mg} \cdot \mathrm{L}^{-1}\right)$ as a function of the cumulative degree days during the cropping cycles of fall (October-December), winter (January-March), and spring (April-May). Letters represent significant $(P<0.05)$ polynomial contrasts of $\mathrm{N}$ concentrations within each degree day as follows: $\mathrm{L}=$ linear; $\mathrm{Q}=$ quadratic; $\mathrm{C}=$ cubic. 
winter cropping cycle was $28 \%$ and $77 \%$ higher than that of 'Dragoon' and 'Buttercrunch', respectively.

NNI ranged from 0.3 , deficient, to 1.4 , luxurious, depending on the growth stage (Fig. 4). Lower values were observed during early growth stage, whereas higher values were recorded at harvest, irrespective of season, $\mathrm{N}$ concentration, or cultivar. Seasonal variations were also observed in NNI. From 21 DAT until harvest in fall, NNI was consistently at or greater than 1.0 , even at the lowest $\mathrm{N}$ supply, regardless of cultivar. In winter and spring cycles, NNI was below 1.0 for all sampling dates for $100 \mathrm{mg} \cdot \mathrm{L}^{-1}$, whereas it remained at or greater than 1.0 for nutrient solution concentrations greater than $200 \mathrm{mg} \cdot \mathrm{L}^{-1}$. It was greater than 1.0 for the two highest N concentrations in 'Sparx' but not in 'Buttercrunch' and 'Dragoon'. Across all seasons and cultivars, NNI increased with increasing $\mathrm{N}$ concentration.

Fresh weight yield and yield components. GDD accumulated from transplanting to harvest were 644,495 , and 530 during fall, winter, and spring seasons, respectively. Fewer days were needed to reach physiological maturity in the spring, 28 DAT, than in fall, 42 DAT, and winter, 35 DAT. Main cultivar, and their two-way interactions, were significant on the fresh weight yield effects of season, $\mathrm{N}$ concentration, and

(Table 1). The effect of the $\mathrm{N}$ concentration $\times$ season interaction suggested that the trend in $\mathrm{N}$ response was dependent on season, with the lettuce cultivar yields following a linear, quadratic, or cubic response to $\mathrm{N}$ concentrations (Fig. 5). In fall, 'Buttercrunch' yield responded linearly $\left(\operatorname{adj} R^{2}=0.80\right.$, $P<0.001$ ), whereas 'Dragoon' and 'Sparx' showed quadratic responses $\left(\operatorname{adj} R^{2}=0.52\right.$, $P>0.05$ and $0.55, P<0.05$, respectively). 'Buttercrunch' yield decreased from 5.5 to $4.1 \mathrm{~kg} \cdot \mathrm{m}^{-2}$ as $\mathrm{N}$ concentration increased from 100 to $400 \mathrm{mg} \cdot \mathrm{L}^{-1}$. However, it should be noted that yield at $100 \mathrm{mg} \cdot \mathrm{L}^{-1} \mathrm{~N}$ was not different from that at higher $\mathrm{N}$ concentration based on Tukey's test. By contrast, yields of 'Dragoon' and 'Sparx' increased either significantly or not as $\mathrm{N}$ concentrations increased from 100 to $300 \mathrm{mg} \cdot \mathrm{L}^{-1}$, followed by a decrease at $400 \mathrm{mg} \cdot \mathrm{L}^{-1}$ (Fig. 5). During winter cycle, a quadratic function fit 'Dragoon' and 'Sparx' yields, whereas 'Buttercrunch' yield was a cubic function of $\mathrm{N}$ concentration. Both 'Dragoon' and 'Sparx' achieved highest yields at $250 \mathrm{mg} \cdot \mathrm{L}^{-1} \mathrm{~N}, 10.6$ and $14.4 \mathrm{~kg} \cdot \mathrm{m}^{-2}$, respectively. However, there was no difference between this yield and that at 150 $\mathrm{mg} \cdot \mathrm{L}^{-1} \mathrm{~N}$. In spring, yields of 'Buttercrunch' and 'Sparx' had a cubic fit to $\mathrm{N}$ concentrations, reaching maximum yields at $150 \mathrm{mg} \cdot \mathrm{L}^{-1} \mathrm{~N}$ of 9.2 and $20.5 \mathrm{~kg} \cdot \mathrm{m}^{-2}$,

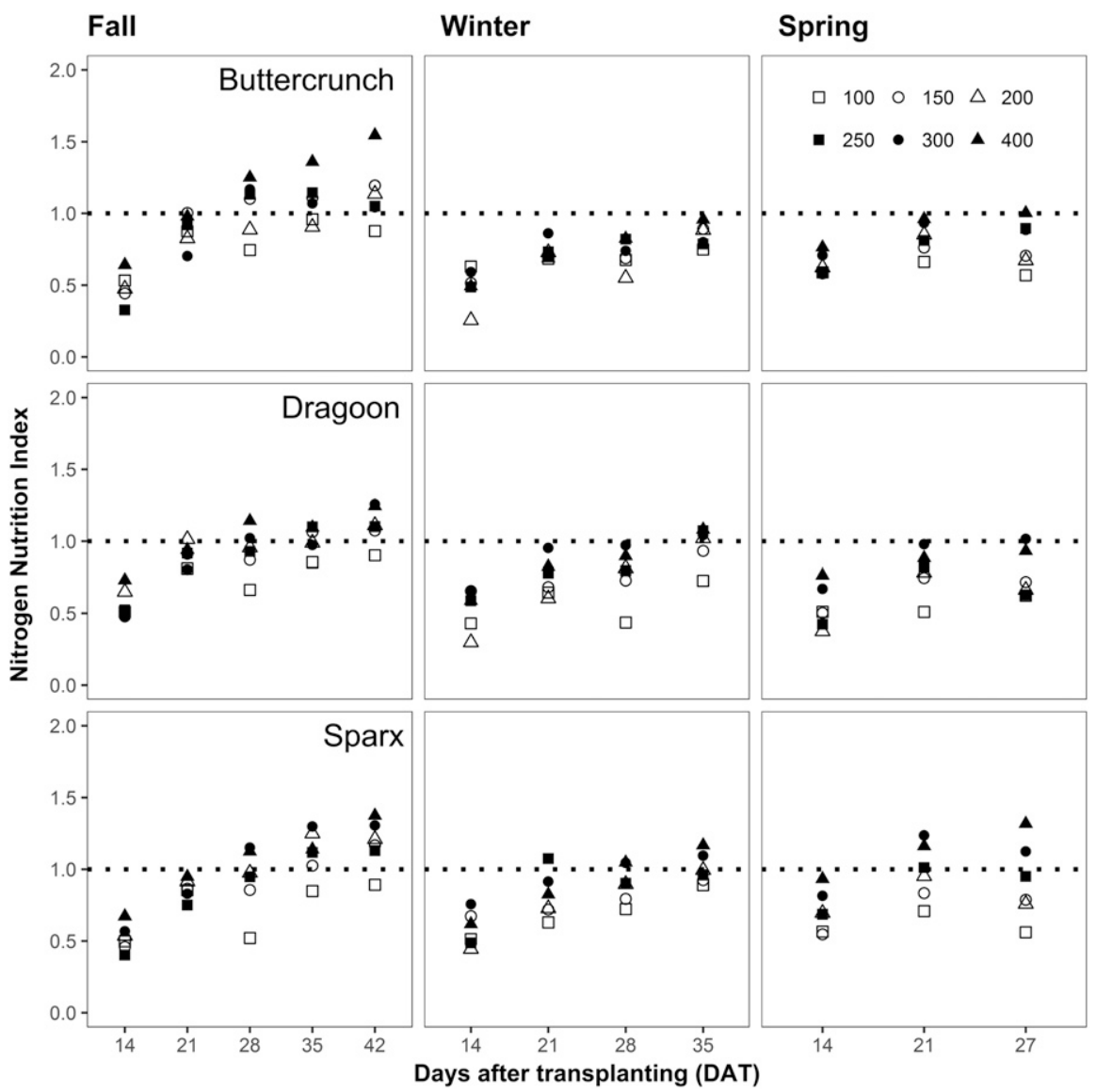

Fig. 4. Changes in nitrogen nutrition index of three lettuce cultivars with time (days after transplanting) at six nutrient solution $\mathrm{N}$ concentrations in nutrient film technique hydroponic culture during fall, winter, and spring seasons. respectively. A quadratic response was observed for 'Dragoon' yield.

Except for 'Buttercrunch' yield in the fall, which decreased linearly in response to increasing $\mathrm{N}$ concentration, increasing $\mathrm{N}$ concentration from 100 to $150 \mathrm{mg} \cdot \mathrm{L}^{-1}$ resulted in a yield increase of $17 \%$ to $40 \%$, whereas concentrations more than $150 \mathrm{mg} \cdot \mathrm{L}^{-1}$ led to no increase or a decrease in yields.

The interaction between the cropping cycle and cultivar was highly significant, which indicates that yield was dependent on the cropping cycle (Table 1). Averaged across all six N concentrations, 'Sparx' had the highest fresh weight yield during each cropping cycle. Compared with 'Buttercrunch' and 'Dragoon', these increases were $63 \%$ and $33 \%$ in fall, $79 \%$ and $52 \%$ in winter, and $145 \%$ and $114 \%$ in spring (data not shown). These results showed that yields were the lowest in fall regardless of cultivar, similar in the winter and spring for 'Buttercrunch' and 'Dragoon', whereas they were highest in spring especially for 'Sparx'. The increased fresh weight yield of 'Sparx' was due to a higher leaf count compared with that of the other two cultivars, as shown in the higher linear relationship between the fresh weight yield and the leaf number per plant (Fig. 6). Independent of nutrient solution $\mathrm{N}$ concentrations, 'Buttercrunch' developed the fewest leaves, whereas 'Sparx' had the most leaves, and the highest yield. During spring, 'Sparx' had 36\% and 22\% more leaves than 'Buttercrunch' and 'Dragoon', respectively, whereas, these increases were $38 \%$ and $29 \%$ during winter cropping cycle.

Nitrogen use efficiency and its components. NUE, NUtE, and NUpE were influenced by season, $\mathrm{N}$ concentration, and cultivar and their two-way interactions. NUE decreased with increasing $\mathrm{N}$ concentration in the nutrient solution (Table 2). Averaged over three seasons, NUE at $100 \mathrm{mg} \mathrm{N} / \mathrm{L}$ was more than that at higher $\mathrm{N}$ concentrations. Similarly, NUE at $150 \mathrm{mg} \cdot \mathrm{L}^{-1}$ was also more than that at higher nutrient solution N. Across all three cultivars, NUE ranged from 2.6 to $4.9 \mathrm{~g}$ $\mathrm{DW} / \mathrm{mg} \mathrm{N}$ at $100 \mathrm{mg} \cdot \mathrm{L}^{-1} \mathrm{~N}$, whereas it varied between 0.6 and $1.6 \mathrm{~g} \mathrm{DW} / \mathrm{mg} \mathrm{N}$ at $400 \mathrm{mg} \cdot \mathrm{L}^{-1} \mathrm{~N}$. At each $\mathrm{N}$ supply, 'Sparx' exhibited the highest NUE across all three seasons, and thus, appeared to be more $\mathrm{N}$ efficient than the other two cultivars. At the lowest $\mathrm{N}$ supply, the NUE of 'Sparx' was $75 \%$ and $88 \%$ more than that of 'Dragoon' and 'Buttercrunch', respectively. Similarly, values of NUpE and NUtE were higher for 'Sparx' at each N level than those of 'Buttercrunch' and 'Dragoon'. The highest values of $\mathrm{NUpE}$ and NUtE were achieved at the lowest $\mathrm{N}$ levels, and these variables were inversely related to increasing $\mathrm{N}$ in the nutrient solution. Averaged over the three cultivars, NUpE decreased from 74 to $33 \mathrm{mg} \mathrm{N} / \mathrm{mg} \mathrm{N}$, whereas NUtE decreased from 46.8 to 30.2 $\mathrm{g} \mathrm{DW} / \mathrm{g} \mathrm{N}$, as $\mathrm{N}$ in the nutrient solution increased from 100 to $400 \mathrm{mg} \cdot \mathrm{L}^{-1}$ (Table 2). NUE, NUtE, and NUpE were the highest for each cultivar in spring. For example, NUtE ranged from 49 to $79 \mathrm{~g} \mathrm{DW} / \mathrm{g} \mathrm{N}$ during 
Table 1. Main effects, two-way, and three-way interactions analysis of variance for fresh weight yield $\left(\mathrm{kg} \cdot \mathrm{m}^{-2}\right)$ in an experiment with three cropping cycles (fall, winter, and spring), six $\mathrm{N}$ concentrations $\left(100,150,200,250,300\right.$, and $\left.400 \mathrm{mg} \cdot \mathrm{L}^{-1}\right)$, and three lettuce cultivars (Buttercrunch, Dragoon, and Sparx). Nitrogen concentrations are partitioned into linear, quadratic, and cubic orthogonal polynomial contrasts.

\begin{tabular}{lrrrr}
\hline Source & df & Sum of squares & $F$ Value & $\operatorname{Pr}>F$ \\
\hline Model & 89 & $2,571.74$ & 28.89 & $<0.0001$ \\
Cycle & 2 & 669.35 & 144.55 & $<0.0001$ \\
N & 5 & 40.24 & 3.48 & 0.0115 \\
Cultivar & 2 & $1,288.37$ & 529.50 & $<0.0001$ \\
Rep(Cycle*N) & 36 & 83.35 & 1.90 & 0.0103 \\
Linear N & 1 & 1.37 & 1.06 & 0.3100 \\
Quadratic N & 1 & 19.23 & 5.80 & 0.0212 \\
Cubic N & 1 & 11.99 & 3.19 & 0.0823 \\
Cycle*Var & 4 & 355.57 & 73.07 & $<0.0001$ \\
Cycle*N & 10 & 65.14 & 2.81 & 0.0110 \\
Linear Cycle*N & 1 & 0.46 & 0.20 & 0.6582 \\
Quadratic Cycle*N & 1 & 0.14 & 0.06 & 0.8070 \\
Cubic Cycle*N & 1 & 14.90 & 6.44 & 0.0157 \\
N*Var $^{*}$ Linear N*Cultivar & 10 & 36.53 & 3.00 & 0.0032 \\
Quadratic N*Cultivar & 1 & 18.56 & 12.80 & 0.0006 \\
Cubic N*Cultivar & 1 & 9.25 & 10.91 & 0.0015 \\
Cycle*N*Cultivar & 1 & 4.00 & 1.73 & 0.1930 \\
Error & 20 & 25.90 & 1.36 & 0.1702 \\
Total & 72 & 87.59 & - & - \\
\hline
\end{tabular}

spring cycle vs. 33-39 g DW/g N during the fall season (data not shown).

\section{Discussion}

Components of growth. Plants absorb $\mathrm{N}$ mainly for the production and maintenance of leaves through enhancement of carbon fixation (Broadley et al., 2000), as well as promoting the production of amino acids, proteins, enzymes, hormones, and other cellular components (Maathuis, 2009). As such, under growth conditions characterized by a decreased $\mathrm{N}$ availability, most plants demonstrated negative growth patterns and reduced yield (Geary et al., 2015). Especially for lettuce, characterized by a high sensitivity to $\mathrm{N}$ deficiency (Broadley et al., 2000), supplementary $\mathrm{N}$ nutrient is required in solution for enhanced plant growth and yield.

Changes in RGR, NAR, LAI, and LAR ascertain differential response of plants to environmental factors. In the present study, leaf count, accumulated DW, and LAI followed logistic patterns over time characterized by a slow increase followed by a rapid increase until maturity. A similar response was reported for lettuce grown in a floating raft hydroponic culture system (Petropoulos et al., 2016) and with potted lettuce grown in sand (Dapoigny et al., 2000). However, regardless of the cultivar or cropping cycle, at each sampling date, response to increasing nutrient solution $\mathrm{N}$ concentration was negligible at the early stage but more pronounced toward mid to late stage. The lack of $\mathrm{N}$ response during the early growth could suggest that growth rate is independent of $\mathrm{N}$ nutrient solution concentration. Lettuce is known to exhibit low $\mathrm{N}$ demand during early growth (Broadley et al., 2000). This can also be related to source/sink balance, whereby more photosynthates are being translocated to ensure root development (sink strength) necessary for increased nutrient solution uptake. At each sampling date, the response of specific growth variable at the late growth was linear, quadratic, or cubic. Fallovo et al. (2009) observed a significant quadratic effect of nutrient solution concentration on lettuce DW and LAI. This could be attributed to the positive $\mathrm{N}$ application effect on leaf area and absorption/utilization of photosynthetically active radiation, which result in increased dry matter (Tei et al., 2003).

Consistent with studies by Gent (2002), our results revealed a clear effect of season and cultivar on the ontogenetic changes in the growth traits evaluated in this study than that of increased nutrient solution $\mathrm{N}$ concentrations. RGR of all three cultivars were the highest during the spring season with plants reaching marketable size earlier (shorter growth cycle) than the other two seasons. Similarly, Dufault et al. (2006) also showed that seasonal differences significantly affected the growth rate and yield of six romaine Cos type lettuce cultivars under field conditions. They found that planting dates in September or April (warmer cropping season) resulted in a shorter growth cycle than those in December or January (cooler cropping season). Environmental factors such as temperature and light are well known to positively influence growth traits (De Pinheiro Henriques and Marcelis, 2000; Gent, 2017; Hatfield and Prueger, 2015). In that sense, higher daytime temperatures during the spring season resulted in more heat unit accumulation, likely leading to greater growth rates due to enhanced photosynthetic functions. Petropoulos et al. (2016) suggested that variation in temperature could explain the higher transpiration and net photosynthetic rate contributing to greater growth traits measured.

Plant $N$ status. Plant nutritional status during growth is determined by the level of
$\mathrm{N}$ supply. In our study, increments in $\mathrm{N}$ resulted in an increase in leaf $\mathrm{N}$ concentrations. This is consistent with findings by Stefanelli et al. (2011) on red oak lettuce and Santamaria et al. (2002) on rocket salad both grown hydroponically. According to Walker et al. (2001), this increased plant $\mathrm{N}$ concentration is the result of these plants under higher nutrient solution $\mathrm{N}$ being unable to sustain the exponential rate of growth needed to convert all of the $\mathrm{N}$ taken up by the roots into new dry matter. During each season, average plant $\mathrm{N}$ concentrations were the highest during the early growth stage (around 14-21 DAT) and then declined steadily over the growth cycle. Seginer et al. (2004) observed similar trend and suggested that during the early growth, lettuce plants generally absorb nutrients faster than its rate of production of assimilates, leading to a transient accumulation of nutrient in the plant tissues. Walker et al. (2001) reported that the decline in tissue $\mathrm{N}$ concentration in the $\mathrm{N}$-fed plants was the result of an augmentation in the amount of structural material (cellulose and other structures) required to support the plants as they became larger. Sosa et al. (2012) measured similar trend and reported that this decrease in $\mathrm{N}$ concentration during the late stage is related to the nutrient dilution effect as the plant allocates a higher amount of assimilates to the heart growth than those partitioned to the rosette formation. The dilution effect could also in part explain the consistently lower $\mathrm{N}$ concentration observed in plants during the spring season relative to other two seasons. Seginer et al. (2004) stated that the rate of dilution could be related to the rate of growth with faster growth rate resulting in faster dilution. In addition, this could also be due to the seasonal differences in irradiance with higher leaf $\mathrm{N}$ concentrations in winter than in spring. In this study, daily light integral ranged from 2.3 to $25.5 \mathrm{~mol} \cdot \mathrm{m}^{-2} \cdot \mathrm{d}^{-1}$ in fall, 2.3 to $31.5 \mathrm{~mol} \cdot \mathrm{m}^{-2} \cdot \mathrm{d}^{-1}$ in winter, and 6.9 to $40.3 \mathrm{~mol} \cdot \mathrm{m}^{-2} \cdot \mathrm{d}^{-1}$ in spring season. It has been shown that tissue $\mathrm{N}$ concentration decreases with high irradiance, as a result of dilution due to more carbohydrate being produced (Gent, 2014). The increase in tissue $\mathrm{N}$ concentrations observed in fall could presumably lead to luxury consumption when supply exceeded demand. This was also confirmed in the values of NNI which were near one or higher than one for all nutrient solution $\mathrm{N}$ levels during the fall season. In addition, whole-shoot tissue $\mathrm{N}$ concentrations at harvest in each cropping cycle appeared within the range of tissue $\mathrm{N}$ concentration reported for lettuce (Hartz et al., 2007), regardless of $\mathrm{N}$ concentration in the nutrient solution. As described by Römheld (2012), this could suggest that $\mathrm{N}$ concentrations in the nutrient solution evaluated in this study are in the adequate range (sufficient levels) ensuring maximum growth performance.

Changes in $\mathrm{N}$ accumulation over time were similar to those in the accumulated biomass with slow increase during the early growth to a maximum at final harvest. This 

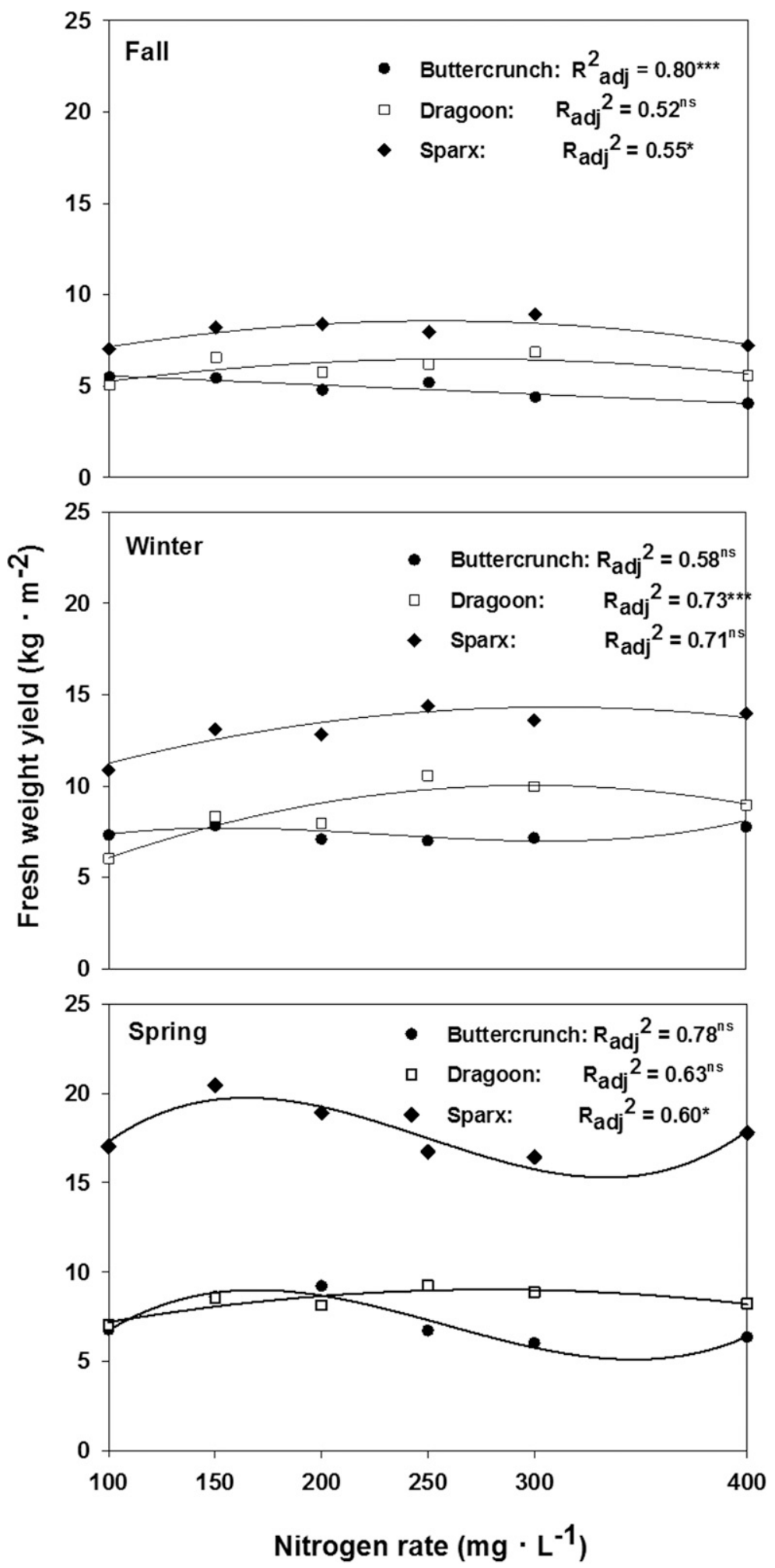

Fig. 5. Responses of fresh weight yield of three lettuce cultivars grown in NFT hydroponic culture at six N concentrations $\left(100,150,200,250,300\right.$, and $\left.400 \mathrm{mg} \cdot \mathrm{L}^{-1}\right)$ in nutrient solutions during fall, winter, and spring seasons. ${ }^{* * *, * * *,}$, Nepresent significant at $P<0.05, P<0.01, P<0.001$, and nonsignificant, respectively. Yields at $100 \mathrm{mg} \cdot \mathrm{L}^{-1} \mathrm{~N}$ are either nonsignificantly or significantly different from 150 $\mathrm{mg} \cdot \mathrm{L}^{-1}$ at $P<0.05$ by Tukey's test.

response pattern is in close agreement with that of Sosa et al. (2012) and suggest that the level of $\mathrm{N}$ accumulated in lettuce plant is determined by the rate of biomass production. season which as previously discussed was also related to the fastest growth rate. 'Sparx' exhibited greater yield stability, having consistently higher level relative to the other two cultivars during each of the three seasons. Earlier studies on lettuce also demonstrated such stability (Dufault et al., 2006). In this study, there was a lack of strong response in fresh weight yield with increasing $\mathrm{N}$ concentrations in the nutrient solution, regardless of the season. This trend substantiated standard relationship between nutrient supply and crop performance as plant growth and yield responses in general reach maximum and remain constant when nutrient supply is within the adequate range (Römheld, 2012). During the three seasons, there was a polynomial trend between $\mathrm{N}$ and yield which varied with cultivar. The linear relationship observed with the yield of 'Buttercrunch' in fall season was negative; characterized by a nonsignificant decreasing trend in yield with increasing solution $\mathrm{N}$. The quadratic response occurred because there was no change in yield as the nutrient solution $\mathrm{N}$ concentration increased beyond $150 \mathrm{mg} \cdot \mathrm{L}^{-1}$. In addition, the cubic effect was observed because yield began to decrease when $\mathrm{N}$ concentration increased from 150 to $200 \mathrm{mg} \cdot \mathrm{L}^{-1}$ but increased again with increasing $\mathrm{N}$ concentration from 300 to $400 \mathrm{mg} \cdot \mathrm{L}^{-1}$. These results are consistent with earlier findings for lettuce in a hydroponic system (Fallovo et al., 2009; Mahlangu et al., 2016) and in field condition (Di Gioia et al., 2017). With wider ranges of nutrient solution $\mathrm{N}$ concentration $(40-2400$ $\mathrm{mg} \cdot \mathrm{L}^{-1}$ ), Stefanelli et al. (2011) observed increase in oak leaf yield grown with perlite substrate to a maximum level at $400 \mathrm{mg} \cdot \mathrm{L}^{-1}$ but there was no statistical difference in yield between $\mathrm{N}$ rates at $400 \mathrm{mg} \cdot \mathrm{L}^{-1}$ and the commercial standard rate (1000-1200 $\mathrm{mg} \cdot \mathrm{L}^{-1}$ ) used in the region (Australia). In this study, except for the negative trend shown with 'Buttercrunch' in the fall, lettuce fresh weight yield increased with increasing $\mathrm{N}$ concentration up to $150 \mathrm{mg} \cdot \mathrm{L}^{-1}$ followed by a slight decrease or constant yield as $\mathrm{N}$ concentration increases. These results suggest that a nutrient solution of $150 \mathrm{mg} \cdot \mathrm{L}^{-1} \mathrm{~N}$ would maximize the fresh weight yield of these cultivars under the conditions of this study.

These results are further supported by the trend observed in NUE which decreased significantly with increasing nutrient solution $\mathrm{N}$ concentration irrespective of the season and cultivar. This decrease is mainly attributed to our observation that $\mathrm{N}$ concentrations higher than $100 \mathrm{mg} \cdot \mathrm{L}^{-1}$ did not result in proportional increase in yield. It is reported that NUE decreases for $\mathrm{N}$ rates greater than the rate required to achieve a critical $\mathrm{N}$ concentration (Benincasa et al., 2011). As such, in this study, the concentration of 100 $\mathrm{mg} \cdot \mathrm{L}^{-1}$ can be considered as the critical $\mathrm{N}$ concentration greater than which these cultivars could exhibit a luxury consumption. 'Sparx' had a higher NUE than 'Dragoon' or 'Buttercrunch'. This increase in NUE was the result of significant increase in both NUtE 

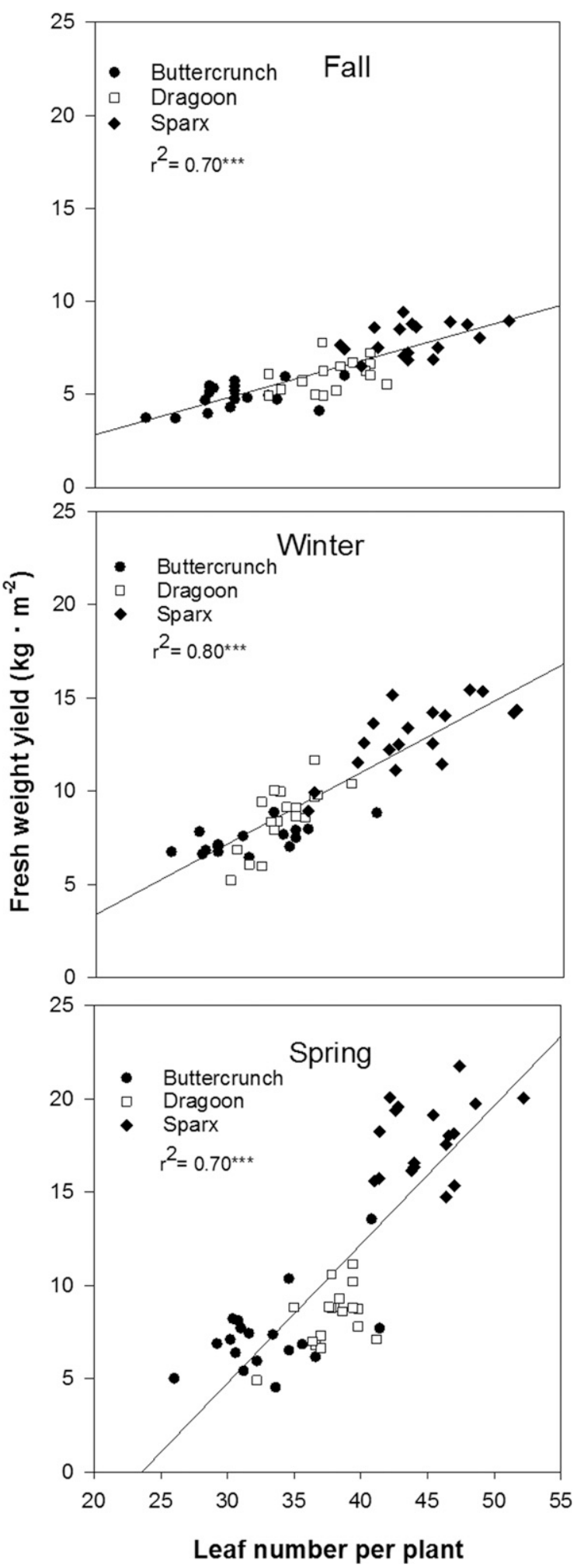

Fig. 6. Linear relationships between fresh weight yield and leaf number per plant of three cultivars of lettuce (Buttercrunch, Dragoon, and Sparx) grown in NFT hydroponic culture at six N concentrations $\left(100,150,200,250,300\right.$, and $\left.400 \mathrm{mg} \cdot \mathrm{L}^{-1}\right)$ in nutrient solutions during fall, winter, and spring seasons. ${ }^{* * *}$ Represents significant at $P<0.001$.

and NUpE. Past studies on NUE and its components suggested that varietal differences in crops NUE are inherent in crop-specific traits (Hirel et al., 2011). Chan-Navarrete et al. (2014) examined 22 commercial cultivars of spinach and found that RGR, leaf area, root DW, chlorophyll content, and specific leaf area better explained the variation in NUE among the cultivars under both low and high $\mathrm{N}$.

Consistent with the observations in yield and NUE, values of NNI were near or greater than one for all six $\mathrm{N}$ rates, especially during the late growth. NNI increased steadily over time, reaching an optimum value during the mid to late growth at harvest. This study also shows that NNI increased with increasing nutrient solution $\mathrm{N}$ with 300 and $400 \mathrm{mg} \cdot \mathrm{L}^{-1}$ consistently leading to NNI higher than 1 . NNI remained close to 1.0 with plants at 150 or $200 \mathrm{mg} \cdot \mathrm{L}^{-1}$ nutrient solution $\mathrm{N}$ during late growth. These results suggested that optimum $(\mathrm{NNI}=1)$ or luxurious $(\mathrm{NNI}>1) \mathrm{N}$ status was measured for $\mathrm{N}$ nutrient solution at $150 \mathrm{mg} \cdot \mathrm{L}^{-1}$ or higher, especially during late growth. This further supports the observation that the crop maximum growth rate is achieved with $\mathrm{N}$ concentration at $150 \mathrm{mg} \cdot \mathrm{L}^{-1}$, while increasing $\mathrm{N}$ concentration beyond 150 $\mathrm{mg} \cdot \mathrm{L}^{-1}$ could lead to luxury consumption and nitrate accumulation especially under low light. This is consistent with previous studies, which used patterns of NNI as a guide to evaluate in-season crop $\mathrm{N}$ status and to assist in optimizing fertilizer $\mathrm{N}$ management program especially in terms of timing and $\mathrm{N}$ application rate (Di Gioia et al., 2017; Lemaire et al., 2008; PeñaFleitas et al., 2015). In a field study on lettuce response to $\mathrm{N}$ input, Di Gioia et al. (2017) concluded that the rate of 120 $\mathrm{kg} \cdot \mathrm{ha}^{-1}$ was sufficient to ensure optimum $\mathrm{N}$ status in the plants based on the temporal changes in NNI.

\section{Conclusions}

In this study, increasing solution $\mathrm{N}$ concentrations had no effects on growth traits during early growth but had affected leaf number, leaf fresh and DW, and LAI during mid to late growth stages. By contrast, these growth traits exhibited greater seasonal and varietal differences with higher growth rates observed in spring than those in fall or winter, mainly due to higher irradiation and light levels. Similarly, the results also indicate a decrease in total plant $\mathrm{N}$ concentration over time, possibly as a result of a nutrient dilution effect. Values of total $\mathrm{N}$ concentration in plants were also higher in fall than those in spring.

The fresh weight yield of the three cultivars evaluated responded differently to increasing $\mathrm{N}$ concentration in the nutrient solution. 'Sparx' exhibited the strongest and most stable yield response, especially in spring. Except for a yield decrease in response to increasing $\mathrm{N}$ concentration in 'Buttercrunch' in fall, increasing the nutrient solution $\mathrm{N}$ greater than $150 \mathrm{mg} \cdot \mathrm{L}^{-1}$ did not increase yield. Based on the trends observed in yields, NUE, and NNI, a N concentration of $100-150 \mathrm{mg} \cdot \mathrm{L}^{-1}$ was sufficient to maximize the growth and fresh weight yields of these lettuce cultivars under the conditions of this study. Given the lack of response observed during early growth, it may be possible to adopt a ramping nutrient solution program, with a 
Table 2. Nitrogen use efficiency (NUE), nitrogen uptake efficiency (NUpE), and nitrogen-utilization efficiency (NUtE) of three lettuce cultivar plants grown hydroponically under six N nutrient solutions. Values are means across three replications and three seasons $(n=9){ }^{\mathrm{z}}$

\begin{tabular}{lcccc}
\hline & & \multicolumn{3}{c}{ Cultivar } \\
\cline { 2 - 5 } Parameters & N concn $\left(\mathrm{mg}^{\circ} \mathrm{L}^{-1}\right)$ & Buttercrunch & Dragoon & Sparx \\
\hline NUE $(\mathrm{g} \mathrm{DW} / \mathrm{mg} \mathrm{N})$ & 100 & $2.8 \mathrm{Ab}$ & $2.6 \mathrm{Abb}$ & $4.9 \mathrm{Aa}$ \\
& 150 & $1.9 \mathrm{Bb}$ & $1.9 \mathrm{Bb}$ & $3.6 \mathrm{Ba}$ \\
& 200 & $1.2 \mathrm{Cb}$ & $1.6 \mathrm{Cb}$ & $2.6 \mathrm{Ca}$ \\
& 250 & $0.9 \mathrm{Cb}$ & $1.1 \mathrm{Db}$ & $2.4 \mathrm{CDa}$ \\
& 300 & $0.8 \mathrm{Cc}$ & $1.1 \mathrm{Db}$ & $1.8 \mathrm{DEa}$ \\
$\mathrm{NUpE}(\mathrm{mg} \mathrm{N} / \mathrm{mg} \mathrm{N})$ & 400 & $0.8 \mathrm{Cb}$ & $0.6 \mathrm{Ecc}$ & $1.6 \mathrm{Ea}$ \\
& 100 & $64.7 \mathrm{Ab}$ & $62.7 \mathrm{Ab}$ & $94.5 \mathrm{Aa}$ \\
& 150 & $55.4 \mathrm{Ab}$ & $54.6 \mathrm{ABb}$ & $81.9 \mathrm{Aa}$ \\
& 200 & $35.3 \mathrm{Bb}$ & $44.4 \mathrm{BCb}$ & $60.2 \mathrm{Ba}$ \\
& 250 & $29.6 \mathrm{Bb}$ & $33.4 \mathrm{Db}$ & $56.9 \mathrm{Ba}$ \\
NUtE $(\mathrm{g} \mathrm{DW} / \mathrm{g} \mathrm{N})$ & 300 & $25.6 \mathrm{Bc}$ & $36.2 \mathrm{CDb}$ & $52.5 \mathrm{Ba}$ \\
& 400 & $30.3 \mathrm{Bb}$ & $21.6 \mathrm{Ec}$ & $46.8 \mathrm{Ba}$ \\
& 100 & $45.2 \mathrm{Ab}$ & $42.1 \mathrm{Ab}$ & $53.1 \mathrm{Aa}$ \\
& 150 & $37.2 \mathrm{Bab}$ & $36.8 \mathrm{ABb}$ & $43.2 \mathrm{Ba}$ \\
& 200 & $34.7 \mathrm{Ba}$ & $37.2 \mathrm{ABa}$ & $41.9 \mathrm{BCa}$ \\
& 250 & $33.8 \mathrm{Bb}$ & $37.1 \mathrm{ABab}$ & $40.9 \mathrm{BCa}$ \\
& 300 & $33.8 \mathrm{Ba}$ & $31.2 \mathrm{BCa}$ & $34.8 \mathrm{CDa}$ \\
& 400 & $30.7 \mathrm{Ba}$ & $27.9 \mathrm{Cb}$ & $32.1 \mathrm{Da}$ \\
\hline
\end{tabular}

${ }^{\mathrm{z}}$ Means within the same column (capital letters) and same row and parameter (small letters) followed by the same letter are not significantly different at $P<0.05$ based on Tukey's test.

relatively low $\mathrm{N}$ concentration that increases to a maximum concentration by mid growth. However, a better understanding of such nutrient management programs deserves further evaluation.

\section{Literature Cited}

Barbosa, G.L., F.D.A. Gadelha, N. Kublik, A. Proctor, L. Reichelm, E. Weissinger, G.M. Wohlleb, and R.U. Halden. 2015. Comparison of land, water, and energy requirements of lettuce grown using hydroponic vs. conventional agricultural methods. Intl. J. Environ. Res. Public Health 12:6879-6891.

Benincasa, P., M. Guiducci, and F. Tei. 2011. The nitrogen use efficiency: Meaning and sources of variation-case studies on three vegetable crops in central Italy. HortTechnology 21:266273.

Bottoms, T.G., R.F. Smith, M.D. Cahn, and T.K. Hartz. 2012. Nitrogen requirements and N status determination of lettuce. HortScience 47:1768-1774.

Broadley, M., A. Escobar-Gutierrez, A. Burns, and I. Burns. 2000. What are the effects of nitrogen deficiency on growth components of lettuce? New Phytol. 147:519-526.

Chan-Navarrete, R., A. Kawai, O. Dolstra, E.T.L. van Bueren, and C.G. van der Linden. 2014. Genetic diversity for nitrogen use efficiency in spinach (Spinacia oleracea L.) cultivars using the Ingestad model on hydroponics. Euphytica 199:155-166.

Dapoigny, L., S. De Tourdonnet, J. Roger-Estrade, M-H. Jeuffroy, and A. Fleury. 2000. Effect of nitrogen nutrition on growth and nitrate accumulation in lettuce (Lactuca sativa L.), under various conditions of radiation and temperature. Agronomie 20:843-855.

De Pinheiro Henriques, A. and L. Marcelis. 2000. Regulation of growth at steady-state nitrogen nutrition in lettuce (Lactuca sativa L.): Interactive effects of nitrogen and irradiance. Ann. Bot. 86:1073-1080.

Delaide, B., S. Goddek, J. Gott, H. Soyeurt, and M.H. Jijakli. 2016. Lettuce (Lactuca sativa L. var. Sucrine) growth performance in complemented aquaponic solution outperforms hydroponics. Water 8:467.
Di Gioia, F., M. Gonnella, V. Buono, O. Ayala, and P. Santamaria. 2017. Agronomic, physiological and quality response of romaine and red oakleaf lettuce to nitrogen input. Ital. J. Agron. $12: 256-261$

Dufault, R.J., B. Ward, and R.L. Hassell. 2006 Planting date and romaine lettuce cultivar affect quality and productivity. HortScience 41:640-645.

Erley, G.S.a., E.R. Dewi, O. Nikus, and W.J. Horst 2010. Genotypic differences in nitrogen efficiency of white cabbage (Brassica oleracea L.). Plant Soil 328:313-325.

Fallovo, C., Y. Rouphael, E. Rea, A. Battistelli, and G. Colla. 2009. Nutrient solution concentration and growing season affect yield and quality of Lactuca sativa L. var. acephala in floating raft culture. J. Sci. Food Agr. 89:1682-1689.

Geary, B., J. Clark, B. Hopkins, and V. Jolley. 2015. Deficient, adequate and excess nitrogen levels established in hydroponics for biotic and abiotic stress-interaction studies in potato. $\mathrm{J}$. Plant Nutr. 38:41-50.

Gent, M. 2002. Growth and composition of salad greens as affected by organic compared to nitrate fertilizer and by environment in high tunnels. J. Plant Nutr. 25:981-998.

Gent, M.P. 2014. Effect of daily light integral on composition of hydroponic lettuce. HortScience 49:173-179.

Gent, M.P. 2017. Factors affecting relative growth rate of lettuce and spinach in hydroponics in a greenhouse. HortScience 52:1742-1747.

Greenwood, D.J., K. Kubo, I.G. Burns, and A. Draycott. 1989. Apparent recovery of fertilizer $\mathrm{N}$ by vegetable crops. Soil Sci. Plant Nutr. 35:367-381.

Haegele, J.W., K.A. Cook, D.M. Nichols, and F.E. Below. 2013. Changes in nitrogen use traits associated with genetic improvement for grain yield of maize hybrids released in different decades. Crop Sci. 53:1256-1268.

Hartz, T.K., P.R. Johnstone, E. Williams, and R.F. Smith. 2007. Establishing lettuce leaf nutrient optimum ranges through DRIS analysis. HortScience 42:143-146.

Hatfield, J.L. and J.H. Prueger. 2015. Temperature extremes: Effect on plant growth and development. Weather Clim. Extrem. 10:4-10.
Hirel, B., T. Tétu, P.J. Lea, and F. Dubois. 2011. Improving nitrogen use efficiency in crops for sustainable agriculture. Sustainability $3: 1452-$ 1485 .

Hunt, R. 1982. Plant growth curves. The functional approach to plant growth analysis. Edward Arnold Ltd, London, UK.

Justes, E., B. Mary, J-M. Meynard, J-M. Machet, and L. Thelier-Huché. 1994. Determination of a critical nitrogen dilution curve for winter wheat crops. Ann. Bot. 74:397-407.

Kristensen, S., E. Friis, K. Henriksen, and S. Mikkelsen. 1987. Application of temperature sums in the timing of production of crisp lettuce. Acta Hort. 198:217-226.

Ladha, J.K., H. Pathak, T.J. Krupnik, J. Six, and C. van Kessel. 2005. Efficiency of fertilizer nitrogen in cereal production: Retrospects and prospects. Adv. Agron. 87:85-156.

Lammerts van Bueren, E.T. and P.C. Struik. 2017. Diverse concepts of breeding for nitrogen use efficiency. A review. Agron. Sustain. Dev. 37:50.

Lemaire, G., F. Gastal, and J. Salette. 1989. Analysis of the effect of $\mathrm{N}$ nutrition on dry matter yield of a sward by reference to potential yield and optimum N content. Proc. XVI Intl. Grassland Congr., Nice, France, 4-11.

Lemaire, G., M-H. Jeuffroy, and F. Gastal. 2008 Diagnosis tool for plant and crop $\mathrm{N}$ status in vegetative stage: Theory and practices for crop $\mathrm{N}$ management. Eur. J. Agron. 28:614-624.

Maathuis, F.J. 2009. Physiological functions of mineral macronutrients. Curr. Opin. Plant Biol. $12: 250-258$

Maboko, M.M. and C.P. Du Plooy. 2017. Response of hydroponically grown cherry and fresh market tomatoes to reduced nutrient concentration and foliar fertilizer application under shadenet conditions. HortScience 52:572578.

Mahlangu, R., M. Maboko, D. Sivakumar, P. Soundy, and J. Jifon. 2016. Lettuce (Lactuca sativa $\mathrm{L}$.) growth, yield and quality response to nitrogen fertilization in a non-circulating hydroponic system. J. Plant Nutr. 39:1766-1775.

Mikel, M.A. 2007. Genealogy of contemporary North American lettuce. HortScience 42:489493.

Peña-Fleitas, M., M. Gallardo, R. Thompson, M. Farneselli, and F. Padilla. 2015. Assessing crop $\mathrm{N}$ status of fertigated vegetable crops using plant and soil monitoring techniques. Ann. Appl. Biol. 167:387-405.

Petropoulos, S.A., E. Chatzieustratiou, E. Constantopoulou, and G. Kapotis. 2016. Yield and quality of lettuce and rocket grown in floating culture system. Not. Bot. Horti Agrobot. 44:603-612.

Putra, P.A. and H. Yuliando. 2015. Soilless culture system to support water use efficiency and product quality: A review. Agr. Agricu. Sci. Proc. 3:283-288.

Resh, H.M. 2012. Hydroponic food production: A definitive guidebook for the advanced home gardener and the commercial hydroponic grower. CRC Press, Boca Raton, FL.

Römheld, V. 2012. Diagnosis of deficiency and toxicity of nutrients, p. 299-312. In: P. Marschner (ed.). Marschner's mineral nutrition of higher plants. 3rd ed. Elsevier/Academic Press, San Diego, CA.

Rouphael, Y., G. Colla, A. Battistelli, S. Moscatello, S. Proietti, and E. Rea. 2004. Yield, water requirement, nutrient uptake and fruit quality of zucchini squash grown in soil and closed soilless culture. J. Hort. Sci. Biotechnol. 79:423-430. 
Santamaria, P., A. Elia, and F. Serio. 2002. Effect of solution nitrogen concentration on yield, leaf element content, and water and nitrogen use efficiency of three hydroponically-grown rocket salad genotypes. J. Plant Nutr. 25:245258.

SAS-Institute. 2014. SAS/STAT 9.4 user's guide. SAS Institute, Inc., Cary, NC.

Seginer, I., P. Bleyaert, and M. Breugelmans. 2004. Modelling ontogenetic changes of nitrogen and water content in lettuce. Ann. Bot. 94:393-404

Sharifi, M., B.J. Zebarth, and W. Coleman. 2007. Screening for nitrogen-use efficiency in potato with a recirculating hydroponic system. Commun. Soil Sci. Plant Anal. 38:359-370.
Simko, I., R.J. Hayes, C.T. Bull, B. Mou, Y. Luo, M.A. Trent, A.J. Atallah, E.J. Ryder, and R.G. Sideman. 2014. Characterization and performance of 16 new inbred lines of lettuce. HortScience 49:679-687.

Sosa, A., J. Padilla, J. Ortiz, and J. Etchevers. 2012. Biomass accumulation and its relationship with the demand and concentration of nitrogen, phosphorus, and potassium in lettuce. Commun. Soil Sci. Plant Anal. 43:121-133.

Stagnari, F., V. Di Bitetto, and M. Pisante. 2007. Effects of $\mathrm{N}$ fertilizers and rates on yield, safety and nutrients in processing spinach genotypes. Scientia Hort. 114:225-233.

Stefanelli, D., S. Winkler, and R. Jones. 2011. Reduced nitrogen availability during growth improves quality in red oak lettuce leaves by minimizing nitrate content, and increasing antioxidant capacity and leaf mineral content. Agr. Sci. 2:477.

Tei, F., P. Benincasa, and M. Guiducci. 2003. Critical nitrogen concentration in lettuce. Acta Hort. 627:187-194.

Tei, F., A. Scaife, and D. Aikman. 1996. Growth of lettuce, onion, and red beet. 1 . Growth analysis, light interception, and radiation use efficiency. Ann. Bot. 78:633-643.

Walker, R.L., I.G. Burns, and J. Moorby. 2001 Responses of plant growth rate to nitrogen supply: A comparison of relative addition and $\mathrm{N}$ interruption treatments. J. Expt. Bot. 52:309 317 . 